\title{
The sex-specific influence of body mass index on the association between serum lipids and cognitive function in Chinese elderly population: data from 2009-2015 CHNS
}

\author{
Jiang Li ( $\sim$ lijiang1979@gmail.com ) \\ China-Japan Friendship Hospital https://orcid.org/0000-0002-1622-2623 \\ Yongtong Cao \\ China-Japan Friendship Hospital \\ Cheng Xiao \\ China-Japan Friendship Hospital
}

\section{Research}

Keywords: Serum lipids, Body mass index, Sex, Cognitive function

Posted Date: December 30th, 2019

DOI: https://doi.org/10.21203/rs.2.19766/v1

License: (c) (i) This work is licensed under a Creative Commons Attribution 4.0 International License. Read Full License 


\section{Abstract}

Objectives: Previous studies reported that the association between lipid levels and cognitive function related with sex, age and specific cognitive domains, but the influence of body mass index (BMI) on this association is limited. This triggered our interest in exploring how serum lipids relate to cognitive function in different BMI levels.

Methods: Data was collected from 2009 wave and 2015 wave of China Health and Nutrition Survey (2009-2015 CHNS). Multivariable linear regression analyses examined serum lipids level as predictors of gender-specific measure of cognitive function in different BMI levels, which were adjusted for age, nationality, BMI, SBP, DBP, smoking status, alcohol consumption and education level.

Results: Cognitive function score have different concentration curves in serum lipids quartile levels in different BMI categories. After adjustment for confounding factors, serum TG was positively associated with cognitive function score in underweight ( $\beta \pm S E: 2.06 \pm 0.88$, $P=0.023)$ and obese ( $\beta \pm S E: 1.44 \pm 0.71, P=0.045)$ male group, and serum HDL-C was positively associated with cognitive function score in overweight ( $\beta \pm S E: 1.89 \pm 0.92, P=0.041)$ and obese female group ( $\beta \pm S E: 5.04 \pm 1.62, P=0.002)$.

Conclusions: The associations of serum lipids with cognitive function differed between different gender groups and were specific to BMI levels. This result indicated that better nutritional status has superior cognitive function performance.

\section{Introduction}

Cognitive impairment is an obvious and important disorder among the elderly and affecting the life of the elderly. It is important to test the physical and mental health and quality of life of elderly individuals(Ma et al. 2019). At present, the prevalence of Alzheimer's disease and mild cognitive impairment in China is $5.1 \%$ and $20.8 \%$, respectively, with approximately 5.9 million elderly people with dementia and 23.9 million elderly people with mild cognitive impairment(Jia et al. 2014). Compared with men, women had a higher prevalence rate of mild cognitive impairment(Wang et al. 2019) and a worse ability of naming(Li et al. 2017). In a study among of Chinese older adults aged 90 years and over(Huang et al. 2009), the prevalence of cognitive impairment was $57.8 \%$ overall and up to $67.2 \%$ among women. Such inconsisitencies might be attributable to sex differences in the lipid profiles, etiology of dementia and methods of cognitive assessment(Lu et al. 2017).

Previous studies speculated that associations of serum lipids with cognitive performance is inversely U-shaped or J-shaped(Lu et al. 2017). These associations implied that participants with extremely low or high levels of serum lipids would be expected to show poorer cognitive performance. The possible pathophysiological mechanisms of high serum lipids with the risk of cognitive decline is that high level of cholesterol can contribute to an overproduction and accumulation of $\beta$-amyloid in the brain(Hughes et al. 2014). And a possible explanation for low serum lipid levels with the risk of cognitive decline is the nutritional status of participants. Participants with malnutrition show alterations in the energetic profile as weight loss, reduced caloric, increased energy requirement, low lipid levels and cognitive function impairment(Oreopoulos et al. 2009; Reitz et al. 2004).

Two reviews concluded that high serum cholesterol associates with cognitive function and the association is strongly age-dependent(van Vliet 2012; van Vliet et al. 2009). But the associations between serum triglyceride (TG) and cognitive function were complicated and related with BMI and sex (Table 1). Yin, Z. X. et al. (Yin et al. 2012) found that high normal plasma TG was association with preservation of cognitive function while lower concentrations were not in the Chinese oldest-old. Two studies reported that lower TG was associated with higher cognitive scores in most cognitive domains (Corley et al. 2015) and better short-term memory (Kanoski and Davidson 2011). Lv, Y. B. et al.(Lv et al. 2016) found that TG was associated with MMSE score, but after adjustment for central obesity and other confounding factors, it was not associated with the risk of cognitive impairment. 
Table 1

Reported association of serum/plasma triglycerides with cognitive function in previous studies

\begin{tabular}{|c|c|c|c|c|c|c|}
\hline Source & $\begin{array}{l}\text { Study/Population/study } \\
\text { design }\end{array}$ & $\begin{array}{l}\text { Cognitive function } \\
\text { assessment } \\
\text { methods }\end{array}$ & $\begin{array}{l}\text { Regression } \\
\text { models }\end{array}$ & $\begin{array}{l}\text { Comparison and } \\
\text { effect estimates } \\
(95 \% \mathrm{Cl})\end{array}$ & $\begin{array}{l}\text { Adjustment for } \\
\text { covariates }\end{array}$ & Main results \\
\hline \multirow[t]{2}{*}{$\begin{array}{l}\text { Yin, Z. X. et al. } \\
\text { (Yin et al. } \\
\text { 2012) }\end{array}$} & \multirow{2}{*}{$\begin{array}{l}\text { The Chinese } \\
\text { Longitudinal Healthy } \\
\text { Longevity Survey } \\
\text { (CLHLS); } 836 \\
\text { participants aged } 80 \\
\text { and older; cross- } \\
\text { sectional study }\end{array}$} & \multirow[t]{2}{*}{$\begin{array}{l}\text { The Mini-Mental } \\
\text { Status } \\
\text { Examination } \\
\text { (MMSE) }\end{array}$} & Model 1 & $\begin{array}{l}0.67(0.52- \\
0.86)^{\star \star}\end{array}$ & $\begin{array}{l}\text { Age, sex, } \\
\text { ethnicity and } \\
\text { education }\end{array}$ & \multirow{2}{*}{$\begin{array}{l}\text { High normal } \\
\text { plasma TG } \\
\text { was } \\
\text { association } \\
\text { with } \\
\text { preservation } \\
\text { of cognitive } \\
\text { function while } \\
\text { lower } \\
\text { concentrations } \\
\text { were not in the } \\
\text { Chinese } \\
\text { oldest-old. }\end{array}$} \\
\hline & & & Model 2 & $\begin{array}{l}0.65(0.50- \\
0.84) \star \star\end{array}$ & $\begin{array}{l}\text { Model } 1 \pm \\
\text { leisure activity, } \\
\text { smoking, } \\
\text { drinking and } \\
\text { systolic blood } \\
\text { pressure }\end{array}$ & \\
\hline \multirow[t]{3}{*}{$\begin{array}{l}\text { Corley, J. et al. } \\
\text { (Corley et al. } \\
\text { 2015) }\end{array}$} & \multirow[t]{3}{*}{$\begin{array}{l}\text { The Lothian Birth } \\
\text { Cohort } 1936 \text { Study; } \\
1043 \text { participants; } \\
\text { cross-sectional study } \\
\text { and follow-up study }\end{array}$} & \multirow[t]{3}{*}{$\begin{array}{l}\text { The Wechsler Adult } \\
\text { Intelligence Scale- } \\
\text { III (WAIS-III) }\end{array}$} & Model 1 & $\begin{array}{l}\text { Standardized } \\
\text { regression } \\
\text { coefficient: } \\
-0.070^{\star}\end{array}$ & Sex, age & \multirow{3}{*}{$\begin{array}{l}\text { Lower TG was } \\
\text { associated } \\
\text { with higher } \\
\text { cognitive } \\
\text { scores in most } \\
\text { cognitive } \\
\text { domains. }\end{array}$} \\
\hline & & & Model 2 & 0.007 & $\begin{array}{l}\text { Model } 1 \pm \text { age } \\
11 \mathrm{IQ}\end{array}$ & \\
\hline & & & Model 3 & 0.006 & $\begin{array}{l}\text { Model } 2 \pm \\
\text { occupational } \\
\text { social class, } \\
\text { statin use, and } \\
\text { history of } \\
\text { cardiovascular } \\
\text { disease }\end{array}$ & \\
\hline \multirow[t]{2}{*}{$\begin{array}{l}\text { Lv, Y. B. et al. } \\
\text { (Lv et al. 2016) }\end{array}$} & \multirow{2}{*}{$\begin{array}{l}\text { The Chinese } \\
\text { Longitudinal Healthy } \\
\text { Longevity Survey } \\
\text { (CLHLS) in 2012; } 2437 \\
\text { participants aged } 65 \\
\text { and older; cross- } \\
\text { sectional study }\end{array}$} & \multirow[t]{2}{*}{$\begin{array}{l}\text { The Mini-Mental } \\
\text { Status } \\
\text { Examination } \\
\text { (MMSE) }\end{array}$} & Model 1 & $\begin{array}{l}\text { Compared with } \\
\text { the lowest tertile: } \\
0.86(0.74-1.00)^{\star}\end{array}$ & $\begin{array}{l}\text { Age, gender, } \\
\text { marital status, } \\
\text { residence and } \\
\text { education level }\end{array}$ & \multirow{2}{*}{$\begin{array}{l}\text { TG was } \\
\text { associated } \\
\text { with MMSE } \\
\text { score in linear } \\
\text { regression } \\
\text { models. But in } \\
\text { multiple } \\
\text { logistic } \\
\text { regression } \\
\text { model, TG } \\
\text { levels were not } \\
\text { associated } \\
\text { with the risk of } \\
\text { cognitive } \\
\text { impairment. }\end{array}$} \\
\hline & & & Model 2 & $0.88(0.76-1.03)$ & $\begin{array}{l}\text { Model } 1 \pm \\
\text { current } \\
\text { cigarette } \\
\text { smoking, } \\
\text { current alcohol } \\
\text { drinking, } \\
\text { central obesity, } \\
\text { sleep quality, } \\
\text { anemia, } \\
\text { hypertension, } \\
\text { type } 2 \\
\text { diabetes } \\
\text { mellitus and } \\
\text { CKD }\end{array}$ & \\
\hline $\begin{array}{l}\text { Ong, K. L. et al. } \\
\text { (Kanoski and } \\
\text { Davidson } \\
\text { 2011) }\end{array}$ & $\begin{array}{l}\text { The Multi-Ethnic Study } \\
\text { of Atherosclerosis } \\
\text { (MESA) study: } 6814 \\
\text { participants; cross- } \\
\text { sectional study and } \\
\text { follow-up study }\end{array}$ & $\begin{array}{l}\text { Cognitive Ablilities } \\
\text { Screening } \\
\text { Instrument (CASI) } \\
\text { version 2, Digit } \\
\text { Symbol Coding } \\
\text { (DSC) and Digit } \\
\text { Span (DS) }\end{array}$ & Model 1 & $\begin{array}{l}\text { Standardized } \\
\text { regression } \\
\text { coefficient: 0.026* } \\
\text { (Digit Symbol } \\
\text { Coding Test) and } \\
\text { - 0.020(Forward } \\
\text { Digit Span Test) }\end{array}$ & $\begin{array}{l}\text { age, sex and } \\
\text { race/ethnicity }\end{array}$ & $\begin{array}{l}\text { Lower TG was } \\
\text { associated } \\
\text { with better } \\
\text { short-term } \\
\text { memory. }\end{array}$ \\
\hline
\end{tabular}




\begin{tabular}{|c|c|c|c|c|c|c|}
\hline Source & $\begin{array}{l}\text { Study/Population/study } \\
\text { design }\end{array}$ & $\begin{array}{l}\text { Cognitive function } \\
\text { assessment } \\
\text { methods }\end{array}$ & $\begin{array}{l}\text { Regression } \\
\text { models }\end{array}$ & $\begin{array}{l}\text { Comparison and } \\
\text { effect estimates } \\
(95 \% \mathrm{Cl})\end{array}$ & $\begin{array}{l}\text { Adjustment for } \\
\text { covariates }\end{array}$ & Main results \\
\hline & & & Model 2 & $\begin{array}{l}0.030 * \text { (Digit } \\
\text { Symbol Coding } \\
\text { Test) and - } \\
0.037 * \text { (Forward } \\
\text { Digit Span Test) }\end{array}$ & $\begin{array}{l}\text { Model } 1 \pm \\
\text { education, } \\
\text { smoking } \\
\text { status, pack- } \\
\text { years of } \\
\text { smoking, } \\
\text { current alcohol } \\
\text { insurance, } \\
\text { foreign born } \\
\text { status, } \\
\text { physical } \\
\text { activity, use of } \\
\text { lipid-lowing } \\
\text { medication, } \\
\text { waist:hip ratio, } \\
\text { height, } \\
\text { diabetes, } \\
\text { hypertension, } \\
\text { CRP level, } \\
\text { fibrinogen } \\
\text { level, } \\
\text { interleukin-6 } \\
\text { level, APOE } \\
\text { genotype, } \\
\text { hypertension } \\
\text { and } \\
\text { concentrations } \\
\text { of other lipids }\end{array}$ & \\
\hline \multirow[t]{2}{*}{$\begin{array}{l}\text { Reitz, } \\
\text { Christiane et } \\
\text { al. (Reitz et al. } \\
\text { 2004b) }\end{array}$} & \multirow{2}{*}{$\begin{array}{l}4316 \text { Medicare } \\
\text { recipients aged } 65 \text { and } \\
\text { older; cross-sectional } \\
\text { and prospective } \\
\text { community-based } \\
\text { cohort }\end{array}$} & \multirow[t]{2}{*}{ Vascular Dementia } & Model 1 & $\begin{array}{l}\text { Compared with } \\
\text { the lowest } \\
\text { quartile: } \\
0.82(0.54-1.26)\end{array}$ & $\begin{array}{l}\text { sex, age, } \\
\text { education and } \\
\text { race }\end{array}$ & \multirow[t]{2}{*}{$\begin{array}{l}\text { TG was not } \\
\text { related with } \\
\text { the risk of } \\
\text { Vascular } \\
\text { Dementia. }\end{array}$} \\
\hline & & & Model 2 & $0.95(0.58-1.56)$ & $\begin{array}{l}\text { Model } 1 \pm \text { BMI, } \\
\text { APOE } \\
\text { genotype, } \\
\text { diabetes, heart } \\
\text { disease and } \\
\text { hypertension }\end{array}$ & \\
\hline \multirow[t]{2}{*}{$\begin{array}{l}\text { Parthasarathy, } \\
\text { V. et al. } \\
\text { (Parthasarathy } \\
\text { et al. 2017) }\end{array}$} & \multirow[t]{2}{*}{$\begin{array}{l}251 \text { participants; cross- } \\
\text { sectional study }\end{array}$} & \multirow{2}{*}{$\begin{array}{l}\text { Standardized } \\
\text { neuropsychological } \\
\text { tests, including the } \\
\text { executive } \\
\text { functioning } \\
\text { measure (EXEC), } \\
\text { and the memory } \\
\text { measure (MEM) }\end{array}$} & Model 1 & $\begin{array}{l}\text { Standardized } \\
\text { regression } \\
\text { coefficient:-13.20* }\end{array}$ & $\begin{array}{l}\text { age, education, } \\
\text { gender, }\end{array}$ & \multirow{2}{*}{$\begin{array}{l}\text { TG levels are } \\
\text { inversely } \\
\text { correlated with } \\
\text { executive } \\
\text { function in } \\
\text { non-demented } \\
\text { elderly adults. }\end{array}$} \\
\hline & & & Model 2 & $-10.47^{\star}$ & $\begin{array}{l}\text { Model } 1 \pm T C \text { TC, } \\
\text { LDL, APOE4 } \\
\text { status, Clinical } \\
\text { Dementia } \\
\text { Rating scores } \\
\text { (CDR) and } \\
\text { white matter } \\
\text { microstructure. }\end{array}$ & \\
\hline
\end{tabular}

Most of research only focused on the total population and did not considered the influence of BMI on these associations, leading to some ambiguity with respect to potential BMI differences in serum lipids and cognitive function. So these inconsistent results and potential relationships triggered our interest in exploring the sex-specific influence of BMI on the association between serum lipids and cognitive function in Chinese elderly population.

\section{Methods}

\section{Setting}

In 1989, the CHNS started and was intended to represent a range of economic and demographic variation in China. Participants of CHNS resided in 12 provinces ((including Heilongjiang, Liaoning, Shandong, Henan, Hubei, Hunan, Jiangsu, Guangxi, Guizhou, Ningxia, Shaanxi and Yunnan) and 3 municipal cities (Beijing, Shanghai and Chongqing). Blood samples were collected and tested for the first time in 2009 wave. 
Details of the study design and sampling strategies are available at the World Wide Web site (https://www.cpc.unc.edu/projects/china) and elsewhere(Popkin et al. 1993; Popkin et al. 2009).

All the documentation and procedures comply with Good Clinical Practice (GCP), Human Ethics Protocol Rules and related Chinese laws. The CHNS project was approved by the office of human research ethics of the University of North Carolina at Chapel Hill and the Human \& Clinical Research Ethics Committee of China-Japan Friendship Hospital.

\section{Data collection methods}

Trained interviewers (physicians and nutritionists) used a validated questionnaire to collect demographic, anthropometric, lifestyle, memory status and perceived stress index data. Height and weight were measured by trained interviewers based on a standard protocol, which is similar to the National Health and Nutrition Examination Survey protocol developed by the US National Center for Health Statistics. Height was measured to the nearest $0.1 \mathrm{~cm}$, and weight in lightweight clothing was measured to the nearest $0.1 \mathrm{~kg}$.

Trained phlebotomists drew fasting blood from participants' antecubital vein in the morning under a standard protocol. Blood samples were transferred to the local hospital for further treatment within 2 hours of collection. The samples were centrifuged at $3000 \mathrm{~g}$ for $10 \mathrm{minutes}$ at room temperature as soon as possible and separated into 9 aliquots. Except for the samples for field testing, other samples were storage in -80 degree freezers.

Serum triglycerides (TG), total cholesterol (TC), high-density lipoprotein cholesterol (HDL-C) and low-density lipoprotein cholesterol (LDL-C) were detected using the enzymatic colorimetric method (Kyowa, Japan). The calibrators and control serums were provided by the Department of Laboratory Medicine of China-Japan Friendship Hospital and had the same lot number.

\section{Definition of body size phenotypes and BMI levels}

BMI was calculated as weight in $\mathrm{kg}$ divided by height in square metres. Participants were classified as underweight $\left(\mathrm{BMI}<18.5 \mathrm{~kg} / \mathrm{m}^{2}\right)$, normal

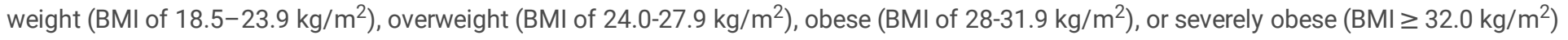
(Group 2004)

\section{Assessment of memory status and cognitive function}

The global cognitive score was calculated using composite scores of memory, counting back and subtraction scores. The cognitive screening items of questionnaire used in CHNS included a subset of items from the Telephone Interview for Cognitive Status-modified (Plassman et al. 1995; Shi et al. 2019). The questionnaire included two questions for assessing self-reported memory status and four tests for testing memory performance. The first question asked about memory status: "How is your memory?" The response categories were "very good", "good", "OK", "bad" and "very bad". Those who reported "bad" or "very bad" were defined as having a poor memory. The second question asked about changes in memory status: "In the past twelve months, how has your memory changed?" The response categories were "improved", "stayed the same" and "deteriorated". Those who reported "deteriorated" were defined as self-reported memory decline.

The following four tests were related to cognitive function on specific memory tasks. Four tests were administered in the following order: 1) the first was a word list memory test for immediate memory, in which an examiner read a list of 10 unrelated words at 2-second intervals and immediately asked the participant to repeat to them as many words as possible in any order (score 10); 2) the following two tests were mind control ability tests in which an examiner counted backward from 20 to 1 (score 2) and calculated 100 minus 7 and subtracted 7 again and again (score 5); and 3) the last test was a test for delayed memory, in which a list of words were repeated to an examiner after a period of time (score 10). An orientation test was not included in the analysis as it was only assessed in 2015 wave. The cognitive function score was used to assess memory performance, which was the sum of the scores of the four tests and could range from 0-27 points. The Cronbach alpha internal consistency coefficient of this scale was 0.73 , which is above the acceptable cutoff of 0.70 .

\section{Study population}

In total, 15143 CHNS participants were included, and 5256 participants had complete memory status data. After excluding the participants with use lipid lowering agent, 4574 participants remained. After further excluding the participants with missing or incomplete gender, age and education level data, 4538 participants remained. Subsequently, 18 participants with missing BMI data of 2015 wave and 2274 participants with missing biomarker data of 2009 wave were excluded, 2246 participants (1120 men and 1126 women) remained.

Page 5/13 


\section{Statistical methods}

The current study was restricted to 2246 participants to examine the influence of BMI on the association between serum lipids and cognitive function among elderly adults in China. For the baseline characteristics of participants, all data are shown as the means \pm standard deviations (SDs) for normal variables and as medians (interquartile ranges) for skewed variables. Differences in characteristics between two gender groups were tested for significance. The unpaired t-test or Mann-Whitney $U$ test was used to compare the differences between continuous variables, and the chi-square test was used for categorical variables.

Multivariable linear regression analyses examined serum lipids level as predictors of gender-specific measure of cognitive function in different BMI levels, which were adjusted for age, nationality, BMI, SBP, DBP, smoking status, alcohol consumption and education level. The statistical analysis was performed with program R 3.4.3.

\section{Results}

\section{Baseline characteristics of the study participants}

The baseline characteristics of the participants were described separately for different gender groups (Table 2). A total of 2246 participants (1120 men and 1126 women), aged $65.64 \pm 7.52$ years (range, $55-94$ years) with a BMl of $23.98 \pm 3.54 \mathrm{~kg} / \mathrm{m}^{2}$, were included in this study. The women showed higher BMI levels (24.58 \pm 3.64 vs. $23.74 \pm 3.45, \mathrm{P}<0.001)$, lower rates of current smoking $(4.17 \%$ vs. $53.13 \%, \mathrm{P}<0.001)$ and alcohol consumption ( $4.88 \%$ vs. $50.54 \%, \mathrm{P}<0.001)$, lower education level and poorer self-reported memory status than the men. The women also showed higher serum lipids levels than the men, including TG [1.44(1.23) vs. 1.23(1.10), $P<0.001], T C[5.12(1.25)$ vs. 4.80(1.22), $P<$ $0.001]$, HDL-C[1.43(0.48) vs. 1.38(0.49), $P=0.001]$ and LDL-C[3.21(1.21) vs. 2.96(1.14), $\mathrm{P}<0.001]$. Other characteristics were not significantly different. 
Table 2

Baseline characteristics of the study participants in different gender groups

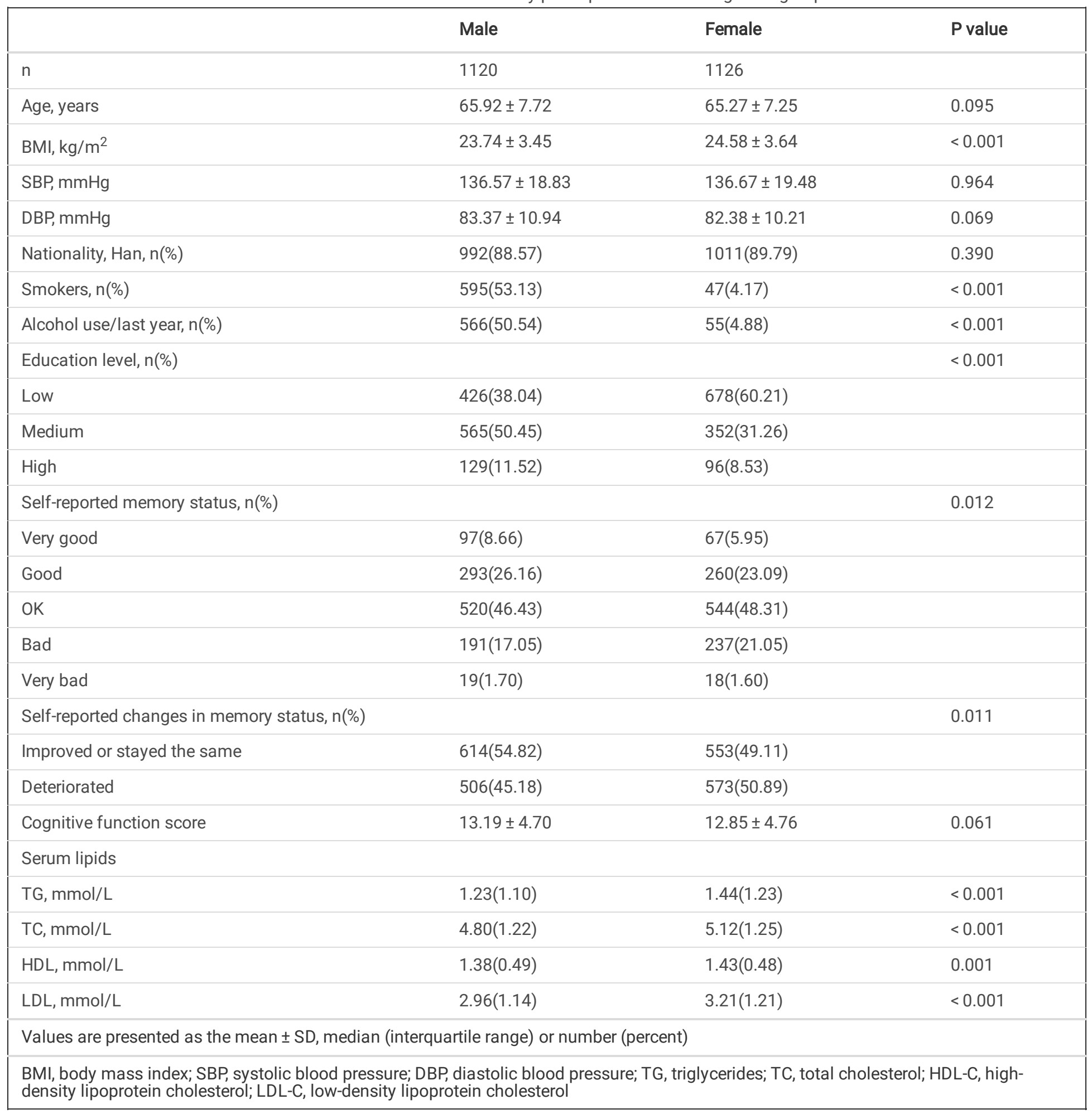

\section{The influence of BMI on the association between serum lipids and cognitive function}

Sex-specific associations between serum lipids and cognitive function in different BMI categories were shown in Fig. 2. Participants were divided into four groups according to quartile values of serum lipids. Cognitive function scores have different curves in different BMI categories. Multivariable linear regression analyses were performed separately to examine the sex-specific association between serum lipids and cognitive function in different BMI categories (Table 3). After adjustment for confounding factors, serum TG was positively associated with cognitive function score in underweight ( $\beta \pm$ SE: $2.06 \pm 0.88, P=0.023)$ and obese $(\beta \pm S E: 1.44 \pm 0.71, P=0.045)$ male group, and serum 
HDL-C was positively associated with cognitive function score in overweight $(\beta \pm$ SE: $1.89 \pm 0.92, P=0.041)$ and obese female group $(\beta \pm S E$ : $5.04 \pm 1.62, P=0.002)$.

Table 3

Sex-specific association of serum lipids with cognitive function score in different BMI categories (Multivariable linear regression)

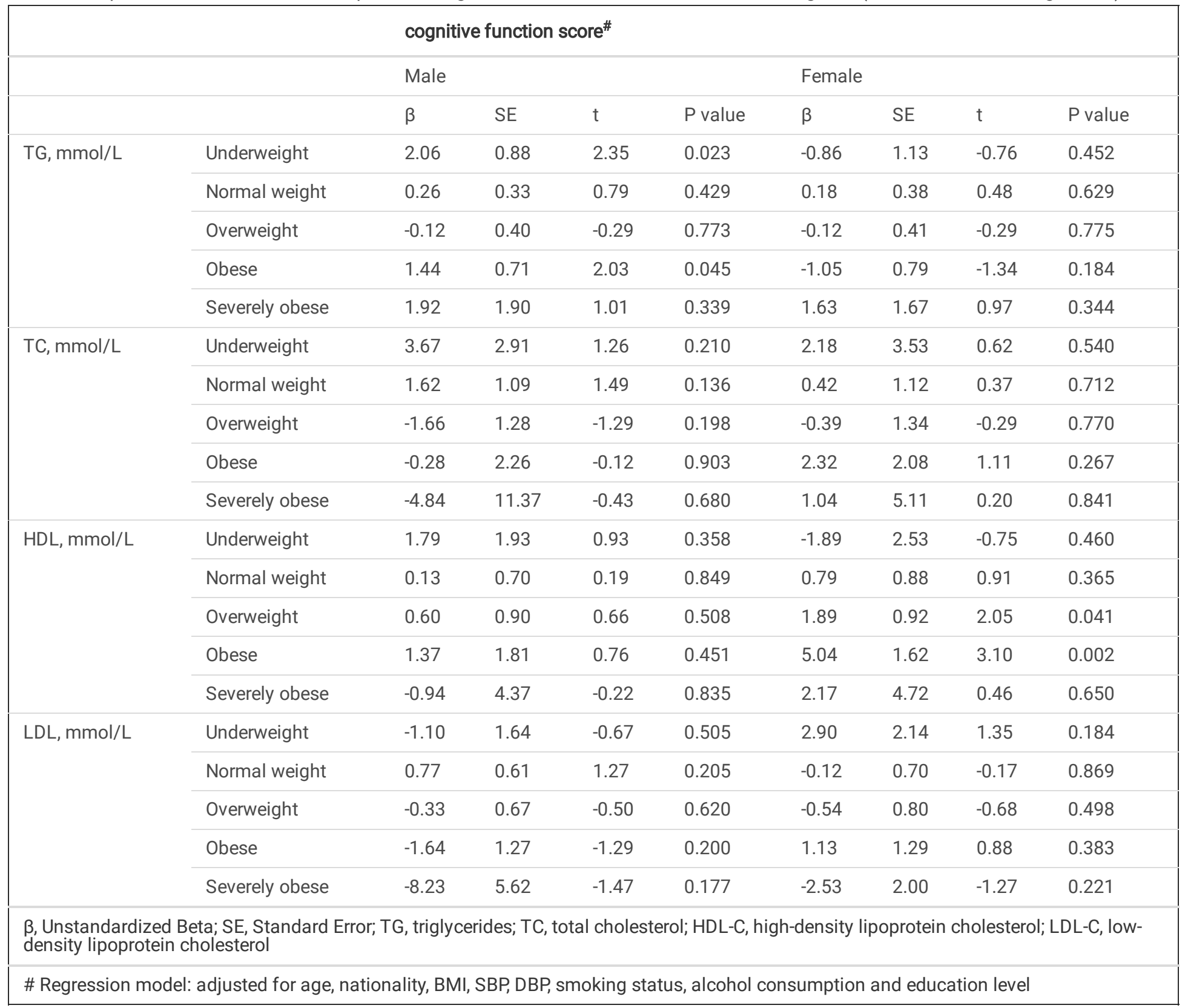

\section{Discussion}

This study investigated the sex-specific influence of BMI on the association between serum lipids and cognitive function in Chinese elderly population for the first time. A total of 2246 participants (1120 men and 1126 women), aged $65.64 \pm 7.52$ years (range, 55-94 years) with a BMI of $23.98 \pm 3.54 \mathrm{~kg} / \mathrm{m}^{2}$, were included in this study. We observed sex-specific associations between serum lipids and cognitive function in different BMI categories and found that serum TG was positively associated with cognitive function score in underweight ( $\beta \pm$ SE: $2.06 \pm 0.88$, $P=0.023)$ and obese $(\beta \pm S E: 1.44 \pm 0.71, P=0.045)$ male group, and serum HDL-C was positively associated with cognitive function score in overweight $(\beta \pm$ SE: $1.89 \pm 0.92, P=0.041)$ and obese female group $(\beta \pm S E: 5.04 \pm 1.62, P=0.002)$.

Accumulating evidence suggests that lipid levels are associated with cognitive function and dementia, but the results showed that the association between lipid levels and cognitive function might be complicated and related with sex(Lu et al. 2017; van Vliet 2012), age(Corley et al. 2015) and specific cognitive domains(Huang et al. 2009). Huang, C. Q. et al.(Lu et al. 2017) speculated that associations of serum lipids with cognitive performance is inversely U-shaped or J-shaped. Solomon et al. (Solomon et al. 2009) reported a bidirectional relationship 
between TC and poor cognitive status and observed a tendency to an interaction between sex and TC changes over time in relation to late-life cognition, but due to size limitation, they could not draw definite conclusions. Ancelin et al (Ancelin et al. 2014) reported that hypercholesterolemic late-life pattern (high TC, low HDL-C, high LDL-C) was related to an increased risk of cognitive function impairment in elderly men. But they also observed an unexpected association with low TC and LDL-C levels at the same time. The possible bidirectional pathophysiological mechanisms of serum lipids with the risk of cognitive decline is that high level of cholesterol can contribute to an overproduction and accumulation of $\beta$-amyloid in the brain(Hughes et al. 2014) and cholesterol is an indispensible component of neuronal and glial membranes(Pfrieger and Ungerer 2011). Participants with malnutrition show alterations in the energetic profile as weight loss, reduced caloric, increased energy requirement, low lipid levels and cognitive function impairment(Oreopoulos et al. 2009; Reitz et al. 2004).

In this study, we observed sex-specific associations between serum lipids and cognitive function. Serum HDL-C was positively associated with cognitive function score in overweight and obese female group. Two prospective studies on metabolic syndrome have examined cognitive decline in women specifically, finding no significant association between low HDL-C or high TG and decline on global cognitive performance (Pirjo et al. 2007; Yaffe et al. 2009). These sex-specific inconsistent associations may be related with genetic vulnerability, serum lipid patterns, hormonal factors and the differences of cognitive function between male and female brains (Ancelin et al. 2014; Casiglia et al. 2008; Neufang et al. 2009).

We also found that serum TG was positively associated with cognitive function score in underweight and obese male group. Serum lipids are considered to be biomarkers of malnutrition (Dana et al. 2009) and serum TG may be a meaningful indicator of nutrition status (Weir et al. 2003; Yin et al. 2012). TGs can increase the blood-brain barrier transport of insulin, which can improve cognition function (Urayama and Banks 2008). And higher serum TG indicates an abundance of circulating fatty acids, which can protect cognitive function and decrease the risk of dementia. This result is similar to some previous studies. Yin, Z. X. et al (Yin et al. 2012) found that high normal plasma TG was associated with preservation of cognitive function in Chinese oldest-old and Ancelin et al.(Ancelin et al. 2014) found that TG levels were associated with a decreased risk of Alzheimer's disease in women. The reasons for these relations remain to be clarified.

Studies on the influence of body mass index on the association between serum lipids and cognitive function are limited. There is no exploring the directly relationship between serum lipids and cognitive function in different BMI levels. Lv, Y. B. et al.(Lv et al. 2016) found that TG was associated with MMSE score, but after adjustment for central obesity and other confounding factors, it was not associated with the risk of cognitive impairment. Of the similar studies which have examined whole samples without BMI stratification, some cross-sectional and prospective studies found inconsistent associations with serum TG (Table 1). The role of serum lipids in different BMI levels in the elderly population remains unclear. Duo to the fact that there are relatively insufficient research about the dyslipidemia and cognitive function with BMI stratification and previous findings have suggested that the impact of extremely low BMI on cognitive function is significant(Suemoto et al. 2015), the present study may be of special importance in filling this gap.

The strengths of this study relate to large sample size of Chinese elderly population to focus on the sex and BMI-specific associations of serum lipids with cognitive function. There were several limitations of our study. First, the number and type of cognitive function tests performed at this study were limited and were not likely to provide particularly precise individual cognitive function score, such as an orientation test was not included in the analysis as it was only assessed in 2015 wave. Second, we had only 1 time point of measurement of serum lipids and assessment of cognitive function. Longitudinal analysis of the temporal relationship between serum lipids levels and cognitive function was not possible. Third, we adjusted the data for multiple confounding factors but cannot exclude the possibility of residual bias due to unmeasured confounders. Fourth, because this was an observational study, our findings could have been confounded by indication bias and cannot show direct causality of BMI and serum lipids with cognitive function. Last, although participants who use lipidlowering agent were excluded, but we cannot exclude participants with hormone treatment.

\section{Conclusions}

In conclusion, we found the relationship between serum lipids and cognitive function was related with BMI levels. Serum TG was positively associated with cognitive function score in underweight and obese male group, and serum HDL-C was positively associated with cognitive function score in overweight and obese female group. Such analytical method needs to be further replicated and it could benefit from corresponding analysis.

\section{List Of Abbreviations}

BMI, body mass index;

CHNS, China Health and Nutrition Survey;

TG, triglyceride; 
TC, total cholesterol;

HDL-C, high-density lipoprotein cholesterol;

LDL-C, low-density lipoprotein cholesterol;

\section{Declarations}

\section{Ethical Approval and Consent to participate}

All the documentation and procedures comply with Good Clinical Practice (GCP), Human Ethics Protocol Rules and related Chinese laws. The CHNS project was approved by the office of human research ethics of the University of North Carolina at Chapel Hill and the Human \& Clinical Research Ethics Committee of China-Japan Friendship Hospital.

\section{Consent for publication}

Written informed consent for publication was obtained from all participants.

\section{Availability of data and material}

Details of the study design, sampling strategies and data are available at the World Wide Web site (https://www.cpc.unc.edu/projects/china)

\section{Competing interests}

All authors declare that they have no conflicts of interest and are in agreement with the content of the manuscript.

\section{Funding}

None

\section{Authors' contributions}

Study design: Jiang Li and Cheng Xiao

Data collection and analysis: Jiang Li and Yongtong Cao

Manuscript preparation: Jiang Li, Yongtong Cao and Cheng Xiao

\section{Acknowledgements}

This research uses data from the China Health and Nutrition Survey (CHNS). We thank the National Institute for Nutrition and Health, China Center for Disease Control and Prevention, Carolina Population Center (P2C HD050924, T32 HD007168), the University of North Carolina at Chapel Hill, the NIH (R01-HD30880, DK056350, R24 HD050924, and R01-HD38700) and the NIH Fogarty International Center (D43 TW009077, D43 TW007709) for financial support for the CHNS data collection and analysis files from 1989 to 2015 and future surveys, and the ChinaJapan Friendship Hospital, Ministry of Health for support for CHNS 2009, Chinese National Human Genome Center at Shanghai since 2009, and Beijing Municipal Center for Disease Prevention and Control since 2011. This work was supported by the National Natural Science Foundation of China (No. 81202766).

\section{References}

1. Ancelin ML et al. (2014) Gender-specific associations between lipids and cognitive decline in the elderly European Neuropsychopharmacology 24:1056-1066

2. Casiglia E et al. (2008) Electrocardiographic criteria of left ventricular hypertrophy in general population European journal of epidemiology 23:261-271 doi:10.1007/s10654-008-9234-6

3. Corley J, Starr JM, Deary IJ (2015) Serum cholesterol and cognitive functions: the Lothian Birth Cohort 1936 International psychogeriatrics 27:439-453 doi:10.1017/S1041610214001197

4. Dana H, Radomir H, Pavel V, Petr K, Miloslav H, Zdenek Z (2009) Serum lipids and neopterin in urine as new biomarkers of malnutrition and inflammation in the elderly Nutrition 25:303-308

5. Group COW (2004) Chinese Adult Overweight and Obesity Prevention and Control Guide (Excerpt) ACTA NUTRIMENTA SINICA 26:1-4 
6. Huang CQ, Dong BR, Wu HM, Zhang YL, Wu JH, Lu ZC, Flaherty JH (2009) Association of cognitive impairment with serum lipid/lipoprotein among Chinese nonagenarians and centenarians Dementia and geriatric cognitive disorders 27:111-116 doi:10.1159/000194660

7. Hughes TM et al. (2014) Markers of cholesterol transport are associated with amyloid deposition in the brain Neurobiology of aging 35:802-807 doi:10.1016/j.neurobiolaging.2013.09.040

8. Jia J et al. (2014) The prevalence of mild cognitive impairment and its etiological subtypesin elderly Chinese Alzheimers \& Dementia $10: 439-447$

9. Kanoski SE, Davidson TL (2011) Western diet consumption and cognitive impairment: links to hippocampal dysfunction and obesity Physiology \& Behavior 103:59-68

10. Li W, Qiu Q, Sun L, Yue L, Wang T, Li X, Xiao S (2017) Sex differences in obesity and cognitive function in a cognitively normal aging Chinese Han population Neuropsychiatric disease and treatment 13:2405-2410 doi:10.2147/NDT.S145245

11. Lu Y et al. (2017) Sex-specific nonlinear associations between serum lipids and different domains of cognitive function in middle to older age individuals Metabolic brain disease 32:1089-1097 doi:10.1007/s11011-017-9999-y

12. Lv YB et al. (2016) Serum Cholesterol Levels within the High Normal Range Are Associated with Better Cognitive Performance among Chinese Elderly The journal of nutrition, health \& aging 20:280-287 doi:10.1007/s12603-016-0701-6.

13. Ma L, Zhang L, Sun F, Li Y, Tang Z (2019) Cognitive function in Prefrail and frail community-dwelling older adults in China BMC geriatrics 19:53

14. Neufang S, Specht K, Hausmann M, Gunturkun O, Herpertz-Dahlmann B, Fink GR, Konrad K (2009) Sex differences and the impact of steroid hormones on the developing human brain Cereb Cortex 19:464-473 doi:10.1093/cercor/bhn100

15. Oreopoulos A, Kalantar-Zadeh K, Sharma AM, Fonarow GC (2009) The obesity paradox in the elderly: potential mechanisms and clinical implications Clinics in geriatric medicine 25:643-659, viii doi:10.1016/j.cger.2009.07.005

16. Pfrieger FW, Ungerer N (2011) Cholesterol metabolism in neurons and astrocytes Progress in lipid research 50:357-371 doi:10.1016/j.plipres.2011.06.002

17. Pirjo K et al. (2007) Metabolic syndrome and cognitive function: a population-based follow-up study in elderly women Dementia \& Geriatric Cognitive Disorders 23:29-34

18. Plassman BL, Welsh KA, Helms M, Brandt J, Page WF, Breitner JC (1995) Intelligence and education as predictors of cognitive state in late life: a 50-year follow-up Neurology 45:1446-1450 doi:10.1212/wnl.45.8.1446

19. Popkin B, Keyou G, Zhai F, Guo X, Ma H, Zohoori N (1993) The nutrition transition in China: a cross-sectional analysis European Journal of Clinical Nutrition 47:333

20. Popkin BM, Du S, Zhai F, Zhang B (2009) Cohort Profile: The China Health and Nutrition Survey-monitoring and understanding socioeconomic and health change in China, 1989-2011 Int J Epidemiol doi:10.1093/ije/dyp322

21. Reitz C, Tang MX, Luchsinger J, Mayeux R (2004) Relation of Plasma Lipids to Alzheimer Disease and Vascular Dementia Archives of Neurology 61:705-714

22. Shi Z, El-Obeid T, Riley M, Li M, Page A, Liu J (2019) High Chili Intake and Cognitive Function among 4582 Adults: An Open Cohort Study over 15 Years Nutrients 11 doi:10.3390/nu11051183

23. Solomon A et al. (2009) Serum total cholesterol, statins and cognition in non-demented elderly Neurobiology of aging 30:1006-1009

24. Suemoto CK, Gilsanz P, Mayeda ER, Glymour MM (2015) Body mass index and cognitive function: the potential for reverse causation Int J Obes (Lond) 39:1383-1389 doi:10.1038/ijo.2015.83

25. Urayama A, Banks WA (2008) Starvation and triglycerides reverse the obesity-induced impairment of insulin transport at the blood-brain barrier Endocrinology 149:3592-3597 doi:10.1210/en.2008-0008

26. van Vliet $P$ (2012) Cholesterol and late-life cognitive decline Journal of Alzheimer's disease : JAD 30 Suppl 2:S147-162 doi:10.3233/JAD2011-111028

27. van Vliet P, van de Water W, de Craen AJ, Westendorp RG (2009) The influence of age on the association between cholesterol and cognitive function Experimental gerontology 44:112-122 doi:10.1016/j.exger.2008.05.004

28. Wang X, Zhou W, Ye T, Lin X, Zhang J (2019) Sex Difference in the Association of APOE4 with Memory Decline in Mild Cognitive Impairment Journal of Alzheimer's disease : JAD 69:1161-1169 doi:10.3233/JAD-181234

29. Weir CJ, Sattar N, Walters MR, Lees KR (2003) Low triglyceride, not low cholesterol concentration, independently predicts poor outcome following acute stroke Cerebrovasc Dis 16:76-82 doi:10.1159/000070119

30. Yaffe K, Weston A, T, Krueger K (2009) The metabolic syndrome and development of cognitive impairment among older women Arch Neurol 66:324-328 
31. Yin ZX et al. (2012) High normal plasma triglycerides are associated with preserved cognitive function in Chinese oldest-old Age and ageing 41:600-606 doi:10.1093/ageing/afs033

\section{Figures}

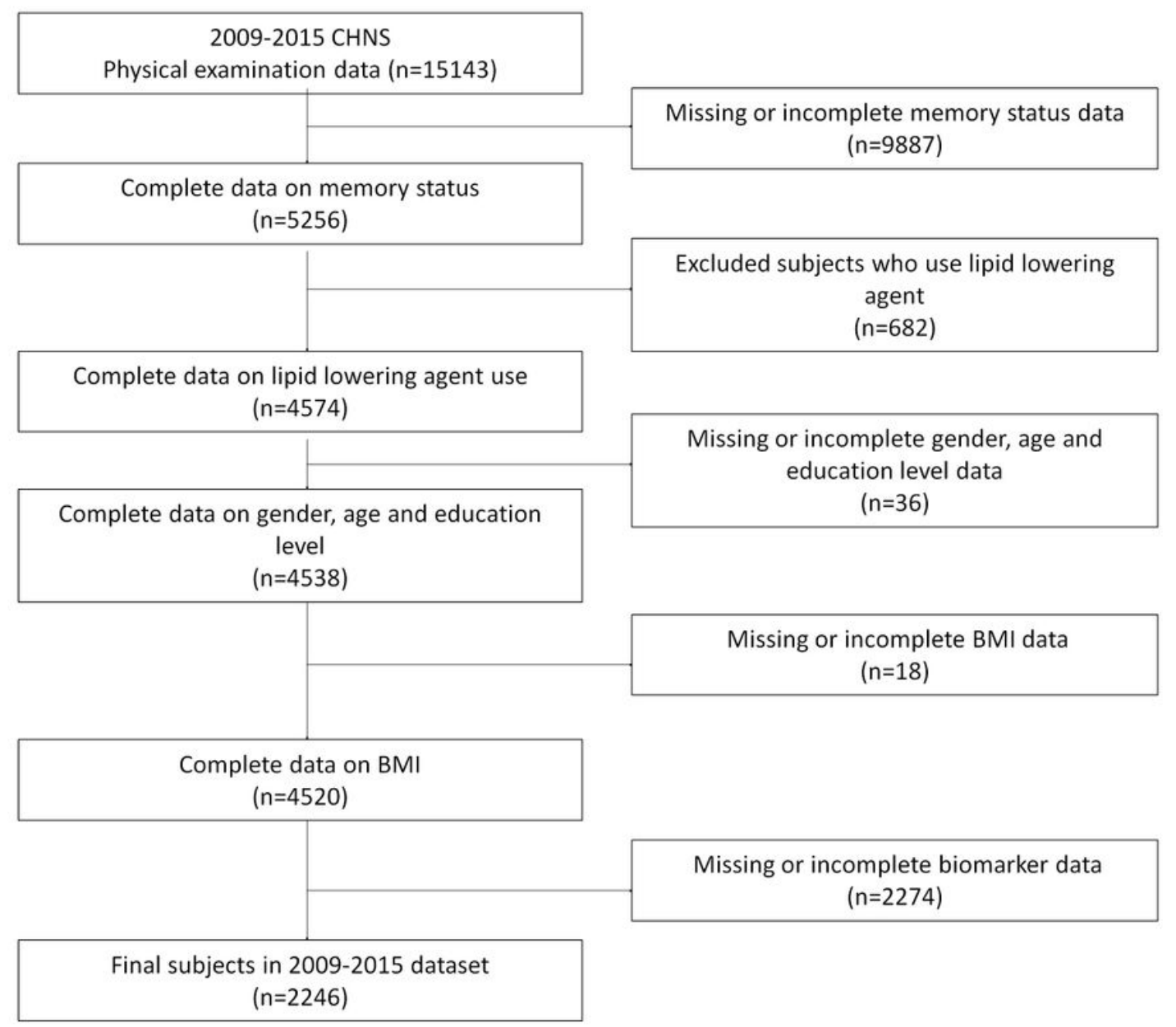

Figure 1

Flow chart of the participant selection 

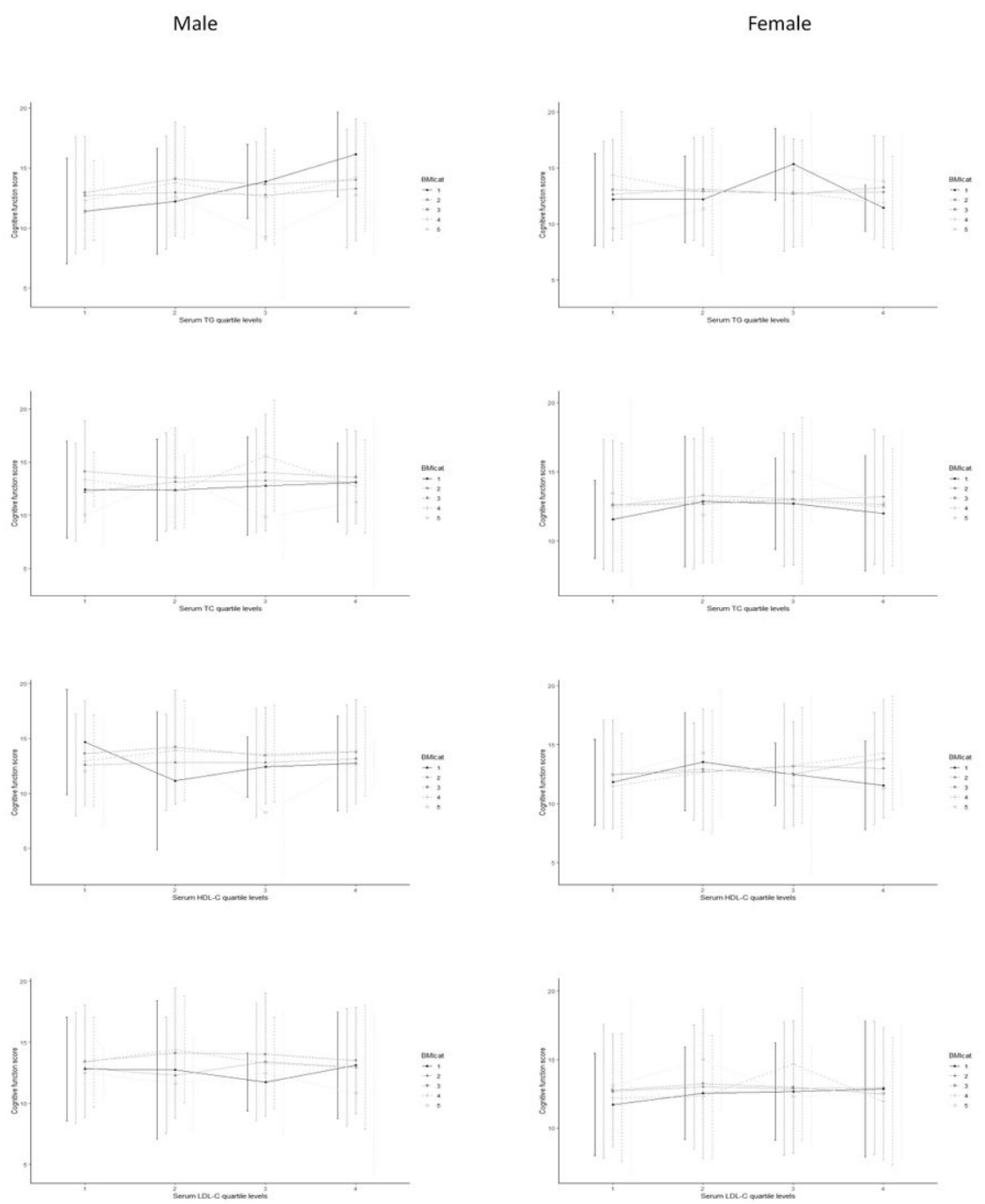

\section{Figure 2}

The influence of BMI on the association between serum lipids and cognitive function 